DOI: $10.2478 / \mathrm{adms}-2014-0023$

\title{
ELECTROCHEMICAL CHARACTERIZATION OF GELATINE DERIVED CERAMICS
}

\begin{abstract}
New materials obtained by pyrolysis of gelatine $(\mathrm{G})$ and poly(1,2-dimethylsilazane) (PSN) (weight ratio: G/PSN 70/30) at temperatures 700 and $900{ }^{\circ} \mathrm{C}$ were characterized by SEM and Raman spectroscopy. The presence of ceramics influences on the cluster size of the materials. Electrochemical tests were performed by cyclic voltammetry and galvanostatic cyclic polarization. The capacity of G/PSN was 464 and $527 \mathrm{mAh} / \mathrm{g}$ for materials pyrolysed at 700 and $900{ }^{\circ} \mathrm{C}$. The capacity fading was $1 \%$ after $17^{\text {th }}$ cycle for G/PSN at $900{ }^{\circ} \mathrm{C}$. This value is higher of $185 \mathrm{mAh} / \mathrm{g}$ in comparison to capacity of gelatine pyrolysed at the same conditions.
\end{abstract}

Key words: Lithium-ion batteries, SICN ceramic materials, hard carbon, anode material

\section{INTRODUCTION}

The graphitized carbons are used as the anode materials in lithium-ion batteries [1]. They can be found in small portable electronic devices such as mobile phones, laptops, cameras. Graphite anodes of theoretical charge capacity equal to $372 \mathrm{mAh} / \mathrm{g}$ are known to be not stable during prolonged cycling and fast charging/discharging processes [2]. Thus, there is still a need to find material with longer cycle life time and better rate capability.

usage of the polymer derived ceramics (PDCs) based on SiCO [3-6] and SiCN [7-9] is one of the way to improve electrochemical performances of anode. On the other hand, it is known that spherical hard carbons prepared from potato starch show reversible capacity, stable cycling performances and good rate capability [10].

In our recent work we have shown that PDCs mixed and pyrolysed with potato starch improved electrochemical properties of such anode in comparison to pyrolysed starch [11]. Here we present electrochemical properties of $\mathrm{SiCN}$ material derived from polysilazane (poly(1,2-dimethylsilazane) M.W. 500-900) mixed and pyrolysed gelatine. The gelatine is inexpensive, environmental friendly and easy to manufacture.

The prepared ceramics derived carbonaceous material, by a one-step programmed heating process under inert atmosphere, was characterized and investigated as anode for Liion batteries. 


\section{EXPERIMENTAL}

Commercially available polysilazane (poly(1,2-dimethylsilazane (PSN2M01 Gelest,M.W. 500-900)was mixed with commercially available gelatine (POCHGliwice). The ratio gelatine to polymer before pyrolysis (G/PSN) was 30/70. The mixture was filled in a ceramic crucible, put into a quartz tube, evacuated, subsequently filled with argon and finally heated under a steady flow of argon (Ar 5.0) $(25 \mathrm{ml} / \mathrm{min})$ in a programmable horizontal tubefurnace (Czylok, Poland) with heating rate of $100{ }^{\circ} \mathrm{C} / \mathrm{h}$. The gelatine/polysilazane blend was crosslinked at $230{ }^{\circ} \mathrm{C}$ for $2 \mathrm{~h}$ followed by heating to the final temperature $\left(700{ }^{\circ} \mathrm{C}\right.$ and 900 ${ }^{\circ} \mathrm{C}$ ) and hold at the final temperature for $2 \mathrm{~h}$. The pyrolysed samples were mechanically milled for 30 minutes, $\mathrm{rpm}=1500$. The electrodes were prepared from a slurry $(80 \mathrm{wt} \%$ of active material, $10 \mathrm{wt} \%$ of carbon black (Super P, Timcal, Switzerland) and $10 \mathrm{wt} \%$ of a binder (polyvinylidene fluoride PVdF, Sole, Germany) in NMP on $\sim 10 \mu \mathrm{m}$ thin copper foil (Schlenk Metallfolien GmbH \& Co KG, German. Dried disc- electrodes were used in twoelectrode Swagelok ${ }^{\circledR}$ cells with lithium foil as a counter and reference electrodes.

Micro-Raman spectra were recorded on a Raman spectrometer inVia Renishaw (Renishaw, England) with an Ar ion laser at a wavelength of $514 \mathrm{~nm}$. The spectral analysis was performed with the software GRAMS/32 (Galactic) with Lorentzian fitting procedure with 5 peaks $\left(\chi^{2}=1.18 \pm 0.3\right)$.

Cyclic voltammetry was performed using an electrochemical potentiostat/galvanostat Autolab (PGStat302N, The Netherlands) between $0.005( \pm 0.001)-3.0( \pm 0.004) \mathrm{V}$ versus $\mathrm{Li} / \mathrm{Li}^{+}$at a scan rate of $100 \mu \mathrm{V} \cdot \mathrm{s}^{-1}$. All measurements were performed at $21( \pm 1){ }^{\circ} \mathrm{C}$.

Galvanostatic cyclic polarization tests were performed with multichannel battery interface ATLAS - SOLLICH 0961 MBI (Poland) with a sequence of stages consisting of different charging/discharging $(\mathrm{C} / \mathrm{D})$ rates: at first supplying 5 cycles at $18.6 \mathrm{~mA} / \mathrm{g}(\mathrm{C} / 20)$, then five polarising cycles at $37.2 \mathrm{~mA} / \mathrm{g}(\mathrm{C} / 10)$, next 5 cycles at $64.4 \mathrm{~mA} / \mathrm{g}(\mathrm{C} / 5)$ and 2 polarising cycles at $18.6 \mathrm{~mA} / \mathrm{g}(\mathrm{C} / 20)$ holding potential limits from $0.005( \pm 0.001)-3.0( \pm$ $0.004) \mathrm{V}$.

\section{RESULTS AND DISCUSSION}

\section{SEM and EDX studies}

In Fig. 1 and Fig 2 SEM images coupled with mapping images of G/PSN $700{ }^{\circ} \mathrm{C}$ and $\mathrm{G} / \mathrm{PSN} 900{ }^{\circ} \mathrm{C}$ composites after mechanical milling are shown.
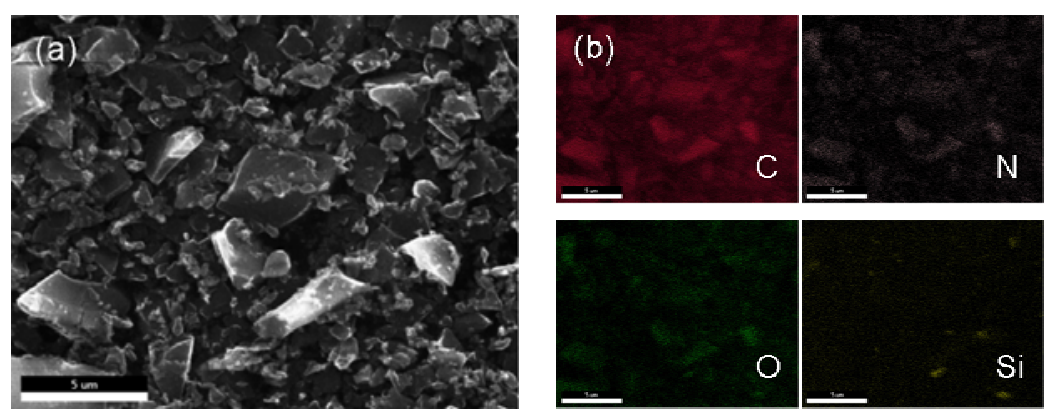

Fig. 1. SEM images (a) and EDX mapping (b) of G/PSN $700^{\circ} \mathrm{C}$ composite 
In the SEM image of G/PSN $700{ }^{\circ} \mathrm{C}$ one may see that the sample exhibits complex morphology. The particles of polyhedron's shape of different sizes are seen. The average size of the milled carbonaceous corpuscles is less than $5 \mu \mathrm{m}$. The EDX mapping of the region shown in Fig 1a is presented in Fig 1b. The data of distribution of elements show that carbon, nitrogen and oxygen are distributed almost uniformly. In the case of silicon distribution is in a form of small islands.
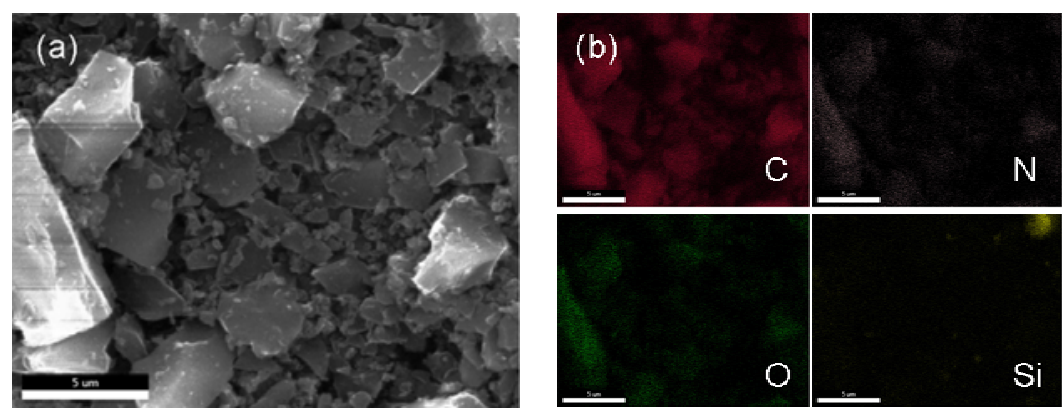

Fig. 2. SEM images (a) and EDX mapping (b) of G/PSN $900^{\circ} \mathrm{C}$ composite

The SEM images of G/PSN pyrolysed at $900{ }^{\circ} \mathrm{C}$ indicate that the material is also consisted of polyhedrons elements of different sizes, see Fig. 2a. In comparison to G/PSN 700 ${ }^{\circ} \mathrm{C}$ the material treated at higher temperature exhibits particles of bigger sizes. Moreover, $\mathrm{G} / \mathrm{PSN} 900{ }^{\circ} \mathrm{C}$ seems to be more compact. The pictures of element distribution evidence that carbon, nitrogen and oxygen are distributed at the same position. Silicon form islands of different diameters as it was observed for G/PSN $700{ }^{\circ} \mathrm{C}$.

The results of the elemental analysis of pyrolysed G/PSN $700{ }^{\circ} \mathrm{C}$ and G/PSN $900{ }^{\circ} \mathrm{C}$ composite are shown in Table 1 . The pyrolysed materials are mainly consisted of carbon originating from pyrolysed gelatine. The total amount of nitrogen is a sum of nitrogen coming from both gelatine and polysilazane.

Table 1. Composition of G/PSN $700^{\circ} \mathrm{C}$ and G/PSN $900^{\circ} \mathrm{C}$ calculated from EDX analysis

\begin{tabular}{|c|c|c|c|c|}
\hline \multirow{2}{*}{ Material } & \multicolumn{4}{|c|}{ Atomic \% } \\
\cline { 2 - 5 } & $\mathrm{C}$ & $\mathrm{N}$ & $\mathrm{O}$ & $\mathrm{Si}$ \\
\hline G/PSN $700^{\circ} \mathrm{C}$ & $65.00 \pm 2.08$ & $26.59 \pm 2.68$ & $8.40 \pm 0.85$ & $0.01 \pm 0.0012$ \\
G/PSN $900^{\circ} \mathrm{C}$ & $67.38 \pm 2.17$ & $24.75 \pm 2.54$ & $7.78 \pm 0.80$ & $0.09 \pm 0.0039$ \\
\hline
\end{tabular}

Both materials are mainly consisted of carbon and nitrogen. The amount of silicon is very low. It can be seen that temperature increase diminishes the amount of nitrogen and oxygen atoms left in the materials. Contrary, the amount of carbon and silicon increases with the temperature.

\section{Raman spectroscopy}

Micro-Raman-spectroscopy was applied to determine the structure of carbon phase in the samples. The spectra of the composite materials G/PSN pyrolysed at $700{ }^{\circ} \mathrm{C}$ and $900{ }^{\circ} \mathrm{C}$ are shown in Fig 3a and Fig 3b, respectively. Deconvoluted Raman spectra are presented in the insets. 

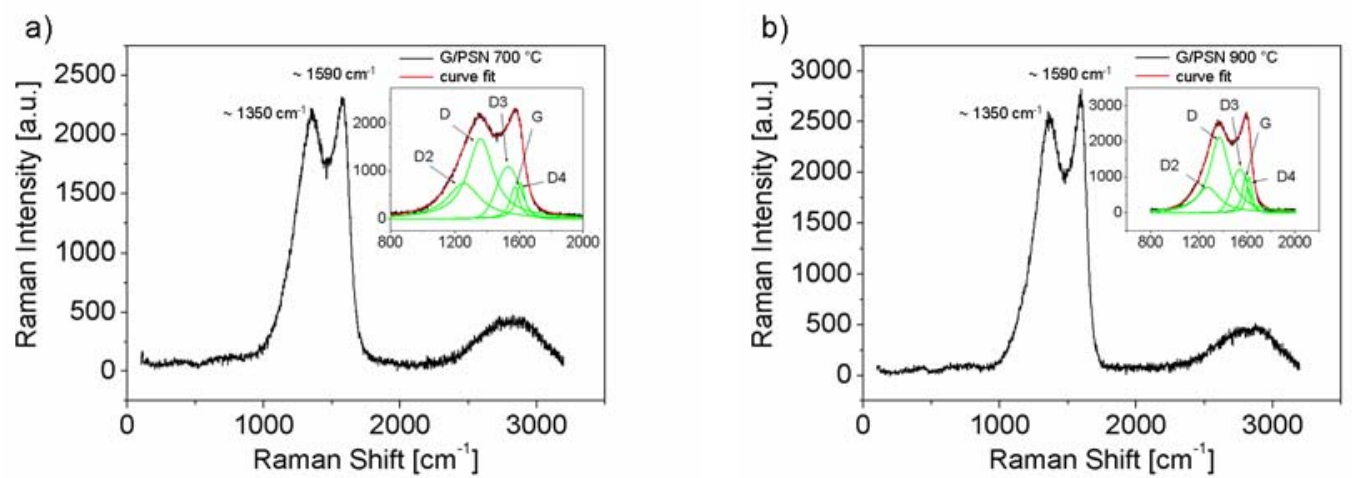

Fig. 3. The Raman spectra of thermally treated a) G/PSN $\left.700^{\circ} \mathrm{C}, b\right) \mathrm{G} / P S N 700^{\circ} \mathrm{C}$ Inset: Deconvolution of Raman spectrum in the range $800-2000 \mathrm{~cm}^{-1}$

The maxima at about $1350 \mathrm{~cm}^{-1}$ and $1590 \mathrm{~cm}^{-1}$, typical for disordered carbonaceous materials, are known as D and G peaks [12]. These maxima confirms the presence of C-C stretching vibrations of $\mathrm{sp}^{2}$ hybridization and the appearance of aromatic rings [13].

A general expression that gives the $L_{\mathrm{a}}$ cluster size parameter calculated from the integrated intensity (areas) ratio $I_{D} / I_{G}$ was estimated with the equation proposed in Ref. [14]:

$$
L_{a}(n m)=\left(2.4 \cdot 10^{-10}\right) \cdot \lambda_{l}^{4} \cdot\left(\frac{I_{D}}{I_{G}}\right)^{-1}
$$

where $\lambda_{l}$ is the laser wavelength $(514.5 \mathrm{~nm})$.

The calculated in-plane crystallite sizes $\left(L_{\mathrm{a}}\right)$ of studied materials are gathered in Table 3:

Table 3. The in-plane correlation length of the materials

\begin{tabular}{|l|l|}
\hline Material & $L_{\mathrm{a}}[\mathrm{nm}]$ \\
\hline Gelatine $700{ }^{\circ} \mathrm{C}$ & 1.96 \\
Gelatine $900{ }^{\circ} \mathrm{C}$ & 2.04 \\
PSN/G $700{ }^{\circ} \mathrm{C}$ & 2.48 \\
PSN/G $900{ }^{\circ} \mathrm{C}$ & 2.68 \\
\hline
\end{tabular}

The two parameters influence on the $L_{\mathrm{a}}$ value: pyrolysis temperature and the presence of the ceramics in the pyrolysed material.

\section{Cyclic voltammetry}

The $1^{\text {st }}$ and $2^{\text {nd }}$ cyclic voltammetry curves obtained for G/PSN electrode materials pyrolysed at $700{ }^{\circ} \mathrm{C}$ and $900{ }^{\circ} \mathrm{C}$ are shown in Fig 4 . 

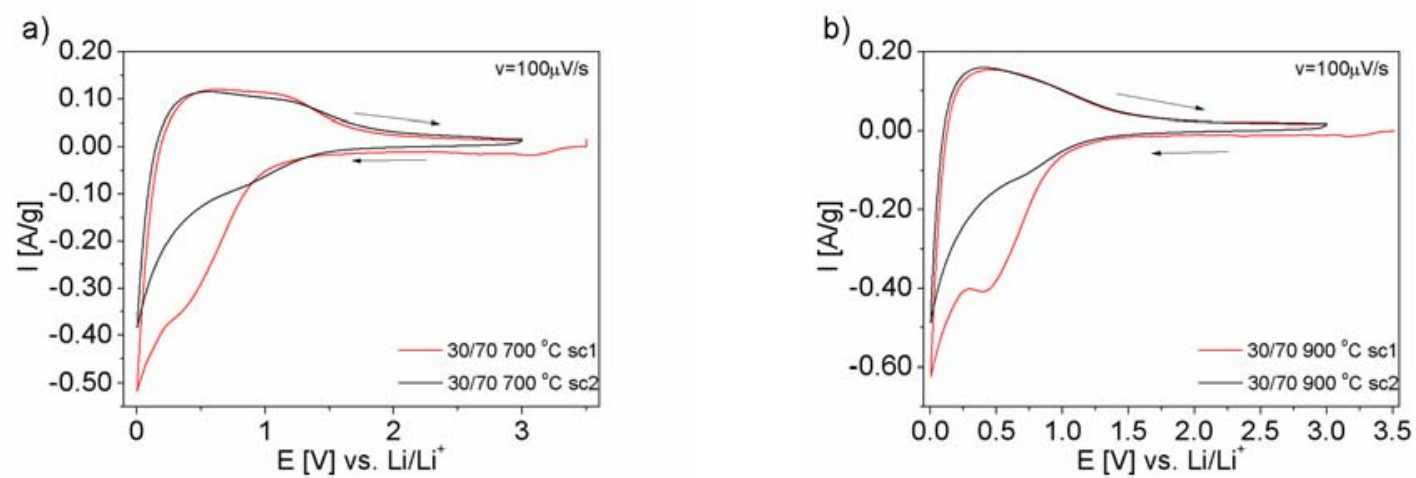

Fig. 4. The first and second $c v$ curve of G/PSN pyrolysed at $700{ }^{\circ} \mathrm{C}$ and $900{ }^{\circ} \mathrm{C}$. Sweep rate $100 \mu \mathrm{V} / \mathrm{s}$. Potential range $0.005-3.0 \mathrm{~V}$ vs. $\mathrm{Li}^{\circ} \mathrm{Li}^{+}$

In both cases the shape of the first cv curve obtained is typical for carbonaceous materials polarized in a broad potential range [12]. The threshold potential at the cathodic branch of the curves is recorded at $\sim 1.0 \mathrm{~V}$ for first scan and at $\sim 0.8 \mathrm{~V}$ for the second scan. The solid electrolyte interface formation and lithium insertion overlap. The lithium $\mathrm{Li}^{+}$ reaction with ceramic part of the electrode material is seen as a broad hump with the current maximum at $\sim+0.37 \mathrm{~V}$ in the second cycle. Extraction process with anodic current maximum at potential $\mathrm{E}=+0.45 \mathrm{~V}$ and at $\mathrm{E}=+0.39 \mathrm{~V}$ for first and second scan is observed.

\section{Galvanostatic cyclic polarization}

In Fig. 5a,b the galvanostatic cyclic polarization of $\mathrm{G} 700{ }^{\circ} \mathrm{C}$ and $\mathrm{G} / \mathrm{PSN} 700{ }^{\circ} \mathrm{C}$ electrodes' materials at different $\mathrm{C}$ - rates are shown. The five charging/discharging cycles at $\mathrm{C} / 20, \mathrm{C} / 10$ and $\mathrm{C} / 5$ following 2 cycles at $\mathrm{C} / 20$ current rate were performed. The capacity values of the last cycle were 448, 291, 217 and $345 \mathrm{mAh} / \mathrm{g}$ for $\mathrm{G} 700{ }^{\circ} \mathrm{C}$ and $522,430,311$ and $464 \mathrm{mAh} / \mathrm{g}$ for $\mathrm{G} / \mathrm{PSN} 700{ }^{\circ} \mathrm{C}$.
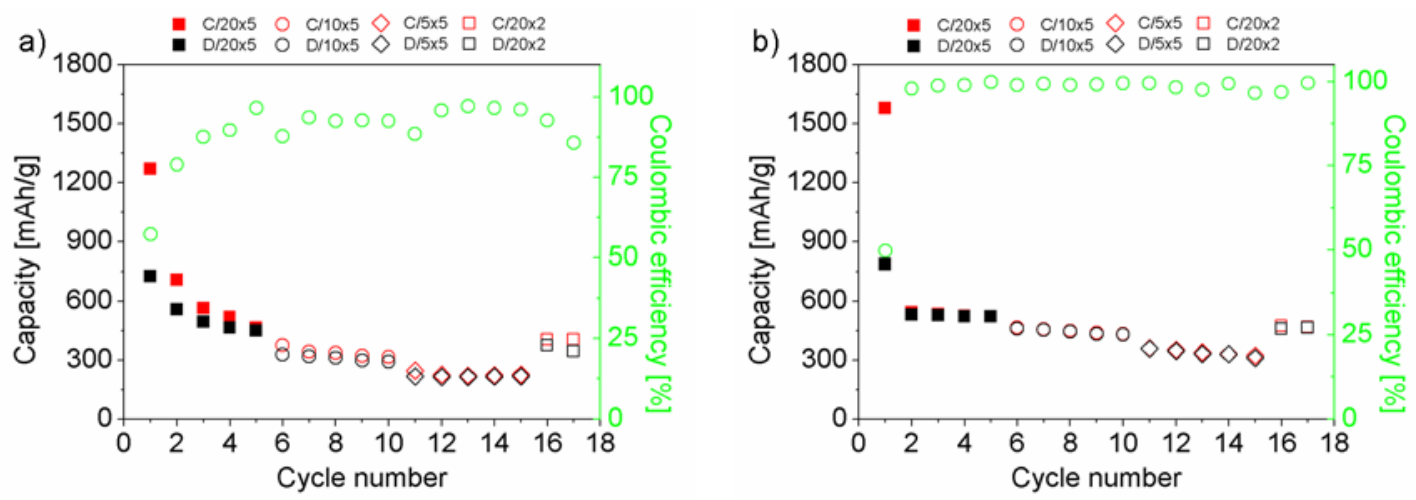

Fig. 5. Cycling performance for the (a) G and (b) G/PSN samples pyrolysed at $700{ }^{\circ} \mathrm{C}$

In Fig 6a,b the capacity vs. cycle number for $\mathrm{G} 900{ }^{\circ} \mathrm{C}$ and $\mathrm{G} / \mathrm{PSN} 900{ }^{\circ} \mathrm{C}$ are presented. The charging/discharging cycles was performed similarly that it was done for materials obtained at lower temperature of pyrolysis. The capacities' values diminishes with the current rate increase in the sequence $\mathrm{C} / 20, \mathrm{C} / 10$ and $\mathrm{C} / 5$ and were 403, 299, 253 for $\mathrm{G}$ $900{ }^{\circ} \mathrm{C}$ and 532,431 and $340 \mathrm{mAh} / \mathrm{g}$ for $\mathrm{G} / \mathrm{PSN} 900{ }^{\circ} \mathrm{C}$. However, the capacity recorded for the final $\mathrm{C} / 20$ rate, performed after $\mathrm{C} / 5$ - rate, was equal to 343 and $527 \mathrm{mAh} / \mathrm{g}$ for $\mathrm{G} 900{ }^{\circ} \mathrm{C}$ and $\mathrm{G} / \mathrm{PSN} 900^{\circ} \mathrm{C}$, respectively. 

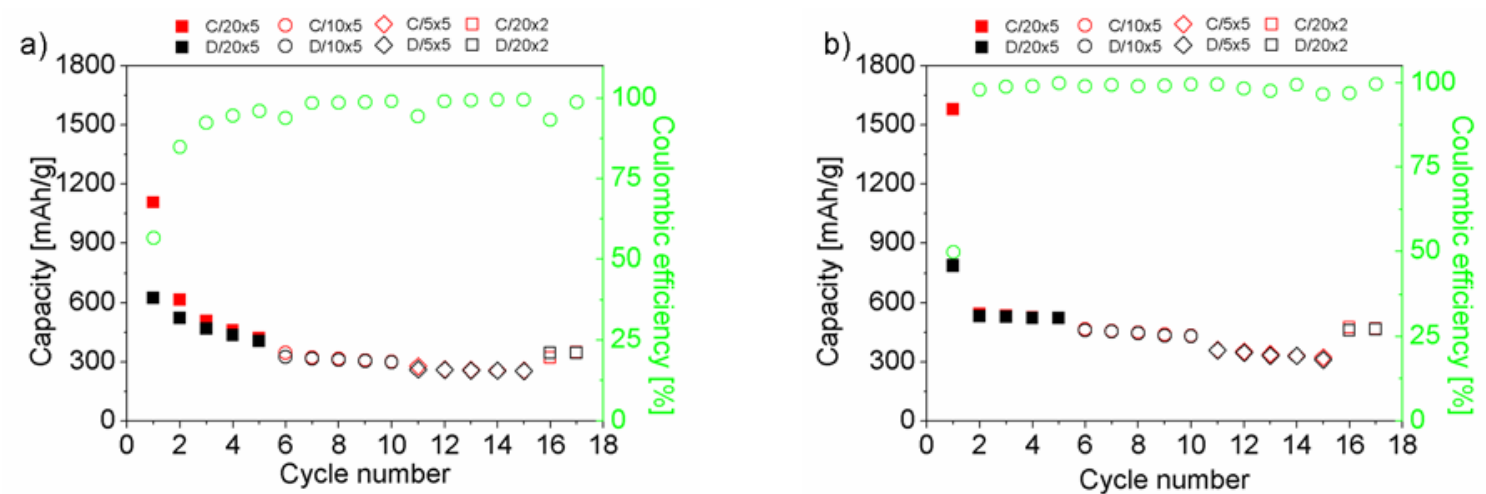

Fig. 6. Cycling performance for the (a) G and (b) G/PSN samples pyrolysed at $900{ }^{\circ} \mathrm{C}$

In both cases, the capacities' values were higher for the pyrolysed materials which were mixed with the preceramic polymer before pyrolysis. These values are higher than theoretical capacity of graphite which is known to be equal $372 \mathrm{mAg} / \mathrm{h}$ [2]. The all studied electrode materials were stable during galvanostatic polarization cycles. The capacity retention of $88.9 \%$ and $99.1 \%$ for $\mathrm{C} / 20$ - rate was achieved for $\mathrm{G} / \mathrm{PSN} 700{ }^{\circ} \mathrm{C}$ and $\mathrm{G} / \mathrm{PSN}$ $900700{ }^{\circ} \mathrm{C}$, respectively. Thus one may conclude that the presence of the ceramics has positive impact on the capacity. Moreover, the temperature of the pyrolysis affects the capacity values. The higher temperature the higher capacity value is.

\section{CONCLUSIONS}

The composite materials obtained from the mixture gelatine/preceramic polymer pyrolysed at $700{ }^{\circ} \mathrm{C}$ and $900{ }^{\circ} \mathrm{C}$ have been characterized. The SEM images show that both, G/PSN $700{ }^{\circ} \mathrm{C}$ and G/PSN $900{ }^{\circ} \mathrm{C}$, materials are consisted of particles of polyhedron's shape. The average size of these particles is less than $5 \mu \mathrm{m}$.

The Raman spectra confirm the presence of disordered carbons in both samples. The cluster size of the carbon particles is 2.48 and $2.68 \mathrm{~nm}$ for G/PSN $700{ }^{\circ} \mathrm{C}$ and G/PSN $900{ }^{\circ} \mathrm{C}$, respectively.

The capacities values of G/PSN materials are higher in comparison to capacities of pyrolysed gelatine taken at the same temperature of about $180 \mathrm{mAh} / \mathrm{g}$. The best capacity performance has been recorded for G/PSN $900{ }^{\circ} \mathrm{C}$ and is equal to $527 \mathrm{mAh} / \mathrm{g}$ for $\mathrm{C} / 20$ with capacity retention of $99 \%$ after $17^{\text {th }}$ cycle. The presence of ceramics has a positive impact on the electrochemical properties of pyrolysed gelatine.

\section{ACKNOWLEDGMENTS}

We gratefully acknowledge the financial support from the National Science Centre, Kraków, Poland (NN 1503/B/H03/2011/40). 


\section{REFERENCES}

1. Pistoia G.: Lithium batteries: New materials, Developments, and Perspectives. Elsevier, Amsterdam, 1994.

2. Takami N., Satoh A., Hara M., Ohsaki T.: Rechargeable Lithium-Ion Cells Using Graphitized Mesophase-Pitch-Based Carbon Fiber Anodes. J Electrochem Soc 142 (1995) 2564-2571.

3. Ahn D., Raj R.: Cyclic stability and C-rate performance of amorphous silicon and carbon based anodes for electrochemical storage of lithium. J Power Sources 196 (2011) 2179-2186.

4. Fukui H., Eguchi K., Ohsuka H., Hino T., Kanamura K.: Structures and lithium storage performance of $\mathrm{Si}-\mathrm{O}-\mathrm{C}$ composite materials depending on pyrolysis temperatures. J Power Sources 243 (2013) 152-158.

5. Sanchez-Jimenez P.E., Raj R.: Lithium Insertion in Polymer-Derived Silicon Oxycarbide Ceramics. J Am Ceram Soc 93 (2010) 1127-1135.

6. Dibandjo P., Graczyk-Zajac M., Riedel R., Pradeep V.S., Soraru G.D.: Lithium insertion into dense and porous carbon-rich polymer-derived SiOC ceramics. J Eur Ceram Soc 32 (2012) 24952503.

7. Graczyk-Zajac M., Toma L., Fasel C., Riedel R.: Carbon-rich SiOC anodes for lithium-ion batteries: Part I. Influence of material UV-pre-treatment on high power properties. Solid State Ionics 225 (2012) 522-526.

8. Kaspar J., Graczyk-Zajac M., Riedel R.: Lithium insertion into carbon-rich SiOC ceramics: Influence of pyrolysis temperature on electrochemical properties. J Power Sources 244 (2013) $450-455$.

9. Graczyk-Zajac M., Mera G., Kaspar J., Riedel R.: Electrochemical studies of carbon-rich polymer-derived SiCN ceramics as anode materials for lithium-ion batteries. J Eur. Ceram. Soc. 30 (2010) 3235-3243.

10. Li W., Chen M., Wang C.: Spherical hard carbon prepared from potato starch using as anode material for Li-ion batteries. Mater Lett 65 (2011) 3368-3370.

11. Nowak A.P., Wicikowska B., Lisowska-Oleksiak A.: New ceramic materials derived from pyrolyzed poly(1,2-dimethylsilazane) and starch as a potential anode for $\mathrm{Li}$-ion batteries. Solid State Ionics 263 (2014) 131-139.

12. Tuinstra F., Koenig J.I.: Raman Spectrum of Graphite. J Chem Phys 53 (1970) 1126-1130.

13. Ferrari A.C., Robertson J.: Interpretation of Raman spectra of disordered and amorphous carbon. Physial Rev B 61 (2000) 14095-14107.

14. Cançado L.G., Takai K., Enoki T., i in.: General equation for the determination of the crystallite size $\mathrm{L}_{\mathrm{a}}$ of nanographite by Raman spectroscopy. Appl Phys Lett 88 (2006) 163106(1)-163106(3). 